Article

\title{
Effects of Substrate on Movement Patterns and Behavior of Stream Fish through Culverts: An Experimental Approach
}

\author{
Kyla Johnson ${ }^{1, *}$, Lindsay E. Wait ${ }^{2}$, Suzanne K. Monk ${ }^{2}$, Russell Rader ${ }^{1}$, Rollin H. Hotchkiss ${ }^{2}$ \\ and Mark C. Belk ${ }^{1}[\mathbb{D}$ \\ 1 Department of Biology, 4102 LSB, Brigham Young University, Provo, UT 84602, USA; \\ russell_rader@byu.edu (R.R.); mark_belk@byu.edu (M.C.B.) \\ 2 Department of Civil and Environmental Engineering, Brigham Young University, Provo, UT 84602, USA; \\ lindsayewait@gmail.com (L.E.W.); smonk@westconsultants.com (S.K.M.); rhh@byu.edu (R.H.H.) \\ * Correspondence: kyla.johnson1229@gmail.com; Tel.: +1-401-262-4907
}

Received: 25 November 2018; Accepted: 15 January 2019; Published: 17 January 2019

\begin{abstract}
Culverts can provide a significant barrier to fish passage by fragmenting fish habitats and impeding the passage success of small-bodied fish. Geographical connectivity is critical to the maintenance of diverse fish assemblages. Culverts with high cross-sectional velocity can cause population fragmentation by impeding passage of small, freshwater fish. Behavioral responses of small fish to high velocities can differ among functional groups, and swimming behavior of many species is not well known. We tested effects of substrate type on swimming behavior in two small, freshwater fish species-southern leatherside chub (Lepidomeda aliciae, a midwater species), and longnose dace (Rhinichthys cataractae, a benthic species) - across three substrate treatments: (1) a bare flume, (2) large flow obstacles, and (3) a natural cobble substrate. Both longnose dace and southern leatherside chub used paths of low velocity and swam in the near-substrate boundary area. Fish in the bare flume and large obstacle treatments swam along the corners of the flume in a straight swim path, whereas fish in the natural substrate treatment used all parts of the flume bed. There was no relationship between passage success of fish and substrate type, fish species, or their interaction. In contrast, substrate type, fish species, and their interaction were significant predictors of passage time. Southern leatherside chub passed through the test section about two to four times faster than longnose dace. Both species took longer to pass through the large flow obstacle treatment compared to the bare flume or natural substrate. The natural substrate created a complex velocity profile with areas of low velocity throughout the entire flume, in contrast to the other two treatments. Our data suggest natural substrates can improve the passage of small fish in high-velocity culverts for both benthic and midwater functional groups.
\end{abstract}

Keywords: fish passage; culvert hydraulics; native fishes; velocity refuge; substrate size

\section{Introduction}

Geographical connectivity to source populations through a network of rivers and streams is critical to the development of diverse fish assemblages. Manmade barriers to fish migration or dispersal have been linked to the decline of freshwater fish assemblages throughout the world [1]. Culverts in streams are ubiquitous in the United States [2,3] and frequently act as barriers to fish passage [2-7]. Recent studies estimate that $30 \%$ to $53 \%$ of culverts are barriers $[2,8]$. These structures adversely affect the survival of freshwater fish species $[3,8,9]$, by preventing migration and fragmenting the habitats of freshwater fish, which leads to increased risk of extinction [10,11]. Culverts can also prevent dispersal [6,11], which is critical for population maintenance and access of spawning habitats [3]. 
Culverts with high velocity profiles fail to accommodate smaller fish, because they do not account for differences in swimming behavior and size-dependent swimming abilities [1,12]. However, correctly retrofitting culverts can effectively restore fish passage [13]. Research on how the morphological and behavioral adaptations of fish affect passage behaviors through culverts will provide valuable information that could inform future culvert design, particularly for small fish $[1,9,14,15]$.

Salmonids are disproportionally represented in studies of fish passage through high-velocity environments [16,17]. In a recent review of fish passage, $77 \%$ of studies examining the ecological impact of culverts included salmonids, whereas $45 \%$ of all fish passage studies concerned salmonids exclusively [11]. Although the passage success of salmonids has historically been prioritized due to commercial value, scientists are now recognizing the importance of passage for other fish species [18,19]. In recent years, studies on lampreys [20-22], perch [1,12,23,24], sculpins [25], sturgeon [26-29], cyprinids [30,31], and galaxiids [32] have increased our knowledge on non-salmonid fish passage. Some species of small-bodied fish exhibit behavioral adaptations that facilitate upstream passage through high-velocity zones by using low-velocity paths. In non-uniform flows, small, weak-swimming fish select paths of low velocity to swim upstream $[14,15,33]$. For example, flume studies document small-bodied fishes consistently swimming in the reduced velocity zone (RVZ) produced by the culvert wall [33,34]. Similarly, many studies have indicated that substrate type may influence passage success in culverts by providing areas of reduced velocity [35-39]. However, given the diversity of behavior and functional form of small fish compared to salmonids, there still is relatively little known regarding the effect of substrate type on navigation of small, freshwater fish through culverts $[3,11]$.

Culverts can become a barrier to fish passage for any species of fish if the design fails to account for a given species' behavioral adaptations [12]. Several studies call for research on adaptive swimming behaviors that might inform culvert design $[11,15,40,41]$. These adaptations include the selection of energy-efficient swim paths and using different swimming strategies. Small fish may use sprint or burst swimming speeds to cross velocity barriers [1,9], or swim at high speeds to minimize passage time [42,43]. Small fish may also conserve energy by taking refuge in areas of reduced velocity [40,44]. Morphological adaptations between functional groups can also influence swimming strategy [28]. Fish in the midwater functional group may take advantage of low-velocity refuges in the wake of obstacles by using "burst-and-coast" swimming [41,44]. Benthic fishes are morphologically adapted to hold position on the substratum by bracing and sheltering [25,45-47]. Behavioral and morphological responses of small fish to high velocities may differ between functional groups, suggesting that culverts designed for the passage of small fish may need to accommodate a range of swimming abilities and strategies, instead of treating small, non-salmonid fish as one group. However, if small fish from different functional groups employ similar swimming strategies for passage, one culvert design may be sufficient to allow for the passage of diverse assemblages of small, non-salmonid stream fish.

To inform culvert design in the context of stream restoration for small-bodied stream fish, species from two different functional groups were selected to model how morphological and behavioral differences between functional groups influences passage behavior and swim paths on different substrates. We tested effects of substrate type on swimming behavior in southern leatherside chub (Lepidomeda aliciae, a midwater species) and longnose dace (Rhinichthys cataractae, a benthic species) across three substrate treatments: (1) a bare flume with no substrate, (2) large obstacles ( $15 \mathrm{~cm}$ diameter), and (3) a natural cobble substrate (see Section 2.2 below). Because longnose dace is a benthic species, we expected it to use bracing behaviors and do best in the natural substrate $[25,45]$. Conversely, we expected southern leatherside chub to use "burst-and-coast" swimming and "refuging" to perform best in the "large obstacle" treatment. We compared the passage time and behavior, and swim paths of southern leatherside chub and longnose dace in each treatment to determine if functional groups (midwater and benthic) react similarly to different velocity profiles. We then quantified fine-scale patterns of velocity generated by the three treatments and mapped the velocity profile of swim paths in each treatment. 


\section{Materials and Methods}

\subsection{Study Species}

Longnose dace are widely distributed across North America [48]. Like other benthic omnivores $[28,29,45,47]$, they exhibit bracing behavior in high velocities, allowing them to endure powerful flows without large increases in energy expenditure [25,45,49]. Southern leatherside chub co-occur with longnose dace in streams in central Utah, USA, as midwater carnivores [50]. These species are not known to undergo spawning migrations, but are most active during the warmest part of the year, i.e., June through August. In Soldier Creek, UT, USA, where specimens were collected for our experiments $\left(39^{\circ} 59^{\prime} 37.5^{\prime \prime} \mathrm{N}, 111^{\circ} 29^{\prime} 42^{\prime \prime} \mathrm{W}\right.$, elevation $=1554 \mathrm{~m}$, gradient $\left.=22.5 \mathrm{~m} / \mathrm{km}\right)$, southern leatherside chub and longnose dace are two of the most abundant fish species, and they co-occur with mottled sculpin (Cottus bairdi), redside shiner (Richardsonius balteatus), mountain sucker (Catostomus platyrhynchus), cutthroat trout (Oncorhynchus clarki), and introduced brown trout (Salmo trutta) and rainbow trout (Oncorhynchus mykiss) [51]. We captured adult longnose dace (mean total length $=82.5 \mathrm{~mm} \pm 3.75 \mathrm{~mm}$; range $=75 \mathrm{~mm}-90 \mathrm{~mm}$ ) and southern leatherside chub (mean TL $=72.5 \mathrm{~mm} \pm 3.75 \mathrm{~mm}$; range $=65 \mathrm{~mm}-80 \mathrm{~mm}$ ) with handheld seine nets (mesh size $=6.5 \mathrm{~mm}$ ) in Soldier Creek during June and July of 2010. We pulled seine nets through pool and riffle environments and collected all fish for a given week over the course of one to two hours.

\subsection{Experimental Design}

We conducted six passage tests each week: three on longnose dace and three on southern leatherside chub over the course of 4 weeks for a total of twelve replicates or trials for both species. This was four trials for each species in each of the three flow treatments described below. We randomly assigned 5 fish from one of the two species to each trial, for a total of 60 fish of both species used in this study. Thus, we collected at least 15 fish of each species at the beginning of each week.

Trials were conducted in a laboratory flume designed to simulate flow conditions in a culvert with a similar diameter (Figure 1). That is, high velocity conditions towards the central portion of the barrel, with reduced velocities near the edges. The flume was made of Plexiglas with an adjustable flow rate, depth, and slope. The recirculating supply of water was equipped with an inline Venturi meter to accurately monitor flow rate, and water velocities were set by manipulating the slope of the flume.

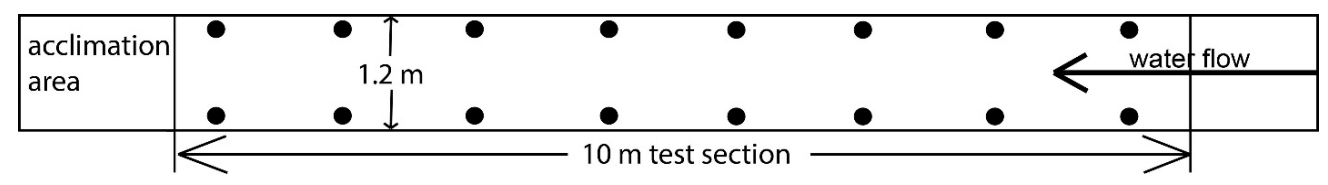

Figure 1. Plan view of the experimental flume representing the bare flume, large obstacle, and natural substrate treatments. Cylinders were placed in the large obstacle treatment only. In the natural substrate and bare flume treatments, the entirety of the experimental flume was covered with cobble substrate or left bare, respectively.

Trials consisted of three treatments: (1) the bare flume representative of bare culverts [32], (2) linearly arrayed obstacles made of concrete cylinders $15 \mathrm{~cm}$ in diameter (see Figure 1), representative of baffles, and (3) natural cobble substrate from the stream where the fish were collected. For the natural substrate trial, we positioned the substrate along the entire length of the flume upstream from the acclimation area, and spanning the entire width of the flume (Figure 1). A standard sieve analyses of four samples showed that the substrate median diameter $\left(\mathrm{d}_{50}\right)$ was $46 \mathrm{~mm}$ with a standard deviation of $6.7 \mathrm{~mm}$.

Fish were allowed to acclimate for one hour in a holding area at a water velocity of $0.20 \mathrm{~m} / \mathrm{s}$ (Figure 1). After the acclimation period, we increased the flow rate until the flume reached the desired cross-sectional average velocity for each test (see below). Once the flow rate was steady, we raised the containment barrier (a mesh panel) to begin a trial. Each trial lasted 60 minutes from the end of the 
acclimation period. In trials with natural substrate, cobbles were extended beyond the test section, such that fish were not suddenly confronted with an abrupt difference in bottom material at the end of the test section. Passage success was the number of fish per trial that traversed the test section of the flume. We also recorded the time for each fish to swim the length of the test section (Figure 1). If fish did not complete the test within 60 minutes, we recorded them as having failed. If a fish did not change position after 15 minutes, we lightly prodded their caudal fin to motivate movement [52]. If fish were impinged against the downstream gate or otherwise exhibited extreme exhaustion with no reaction to prodding, we removed them from the test [1,52].

We mapped fish swim paths by recording the position of each fish at five minute intervals as they moved upstream. Based on visual observations, positions were marked as the distance upstream from the beginning of the test section and the distance from the right edge of the flume. Swim paths were mapped as a sequence of positions with a straight line drawn between positions. Fish were visually monitored during the time between recording intervals (i.e., 5 minutes), but position was not recorded.

The average cross-sectional velocity for each trial was set at $25 \%$ greater than the prolonged swimming speeds for both species, which were $0.54 \mathrm{~m} / \mathrm{s}$ for southern leatherside chub and $0.73 \mathrm{~m} / \mathrm{s}$ for longnose [49]). Prolonged swimming speeds underestimate fish passage [53,54], since fish are often forced to swim above their prolonged swim speeds $[1,49,55]$. For longnose dace, we ran tests at a flow rate of $0.20 \mathrm{~m}^{3} / \mathrm{s}$, a velocity of $0.91 \mathrm{~m} / \mathrm{s}$, a depth of $0.2 \mathrm{~m}$, and a Froude number of 0.66 , whereas flow rate was $0.15 \mathrm{~m}^{3} / \mathrm{s}$, with a velocity of $0.68 \mathrm{~m} / \mathrm{s}$, a depth of $0.16 \mathrm{~m}$, and a Froude number of 0.60 for southern leatherside chub. At these velocities the approach flow was fully developed according to the Blasius equation for flat planes [56], and Reynolds numbers were $>100,000$ for all experiments. To control turbulent surface waves that form at high velocities, which can impact the swimming ability of the fish [9], we tethered a $1 \mathrm{~m}$ long plywood board to the water surface at the inlet section of the flume. This board did not overlap with the test section.

We ran all trials within 4 days of collecting fish [57]. We transported fish to holding tanks (volume $=1100$ liters) in aerated, insulated coolers filled with river water. The holding tanks were kept under $12 \mathrm{~h}$ light and dark cycles at about $18^{\circ} \mathrm{C}$, and fish were fed frozen brine shrimp twice daily. Mean water temperature was also kept at $18{ }^{\circ} \mathrm{C} \pm 4{ }^{\circ} \mathrm{C}$ in the experimental flume. This temperature was in the mid-range of that experienced by fish in Soldier Creek during the growing season [51].

\subsection{Velocity Profiles and Swim Paths}

We used a SonTek 16-MHz Micro Acoustic Doppler Velocimeter (ADV) [58] to generate detailed maps of current velocity for each of our substrate treatments. The ADV is a three-pronged sensor that takes 3D velocity readings in a $\approx 0.3 \mathrm{~cm}^{3}$ sampling volume $5 \mathrm{~cm}$ below the probe tip. ADV output data includes signal to noise ratio (SNR) and correlation (COR) values that filter out noise in the acoustic reflections. COR values are ideally greater than $70 \%$, but COR values as low as $30 \%$ can be used for mean velocity measurements over variable terrain, and SNR values for mean current measurements can be as low as $5 \mathrm{~dB}$. [59]. To reduce the effect of high turbulence near the substrate, only SNR values greater than $5 \mathrm{~dB}$ and COR above 30\% that resulted in at least $70 \%$ good points were include in our analysis. We used the mean water-column velocity to characterize the velocity profile [46]. Velocity measurements were taken along a grid $1 \mathrm{~cm}$ above the substrate on $5 \times 5 \mathrm{~cm}$ planform [14]. We used AutoCad software [60] with the velocity data to map isovels (contours of equal velocity) for a $3.5 \mathrm{~m}$ length of the flume located near the center of the $10 \mathrm{~m}$ test section.

To determine the lowest velocity swim path available to fishes in each of the substrate treatments, we plotted velocity along a simulated continuous swim path. We modeled this minimum velocity swim path after the observed swim paths for each substrate treatment. In the natural substrate treatment, where swim paths were highly variable, we simulated the path of minimum velocity through the measured velocity grid and plotted the resulting velocity profile. To simulate the swim paths, we used an algorithm that assumed fish could move any direction from a given point to follow the path of 
minimum velocity. We mapped minimum velocity profiles of a simulated fish swim path using AutoCad software [60].

\subsection{Statistical Analyses}

We used a logistic analysis of variance (Proc Logistic, SAS 9.3, SAS Institute, Cary, North Carolina) to examine the relationship between the categorical response variable (if individuals successfully traversed the $10 \mathrm{~m}$ test section; yes or no) and the categorical independent variables of fish species (2 levels), substrate treatments (3 levels), and their interaction [61]. For individuals that successfully traversed the test section ( 95 out of 120 individuals), we examined the relationship between passage time (a continuous dependent variable) and fish species (2 levels), substrate treatments (3 levels), and their interaction with a mixed model ANOVA in SAS 9.3 (Proc Mixed) [62]. We used a natural log-transform to meet the assumptions of the parametric model. A replicate trial was a random effect in both analyses.

\section{Results}

\subsection{Swim Paths}

In all substrate treatments, both longnose dace and southern leatherside chub passed through the flume within $1 \mathrm{~cm}$ above the substrate. Swim paths in the control (i.e., bare flume) and large flow obstacle treatments were completely uniform: fish swam in a straight swim path as close as physically possible to the wall of the flume, where velocity was lowest. They entered and exited the test section of the flume in the same position near the walls of the flume. None of the fish in these two treatments moved laterally from one side of the flume to the other. In the large flow obstacles treatment, none of the fish swam along the edge of the cylinders opposite the wall of the flume (i.e., interior edge). Because position of fish was recorded at 5 min intervals, swim paths for the natural substrate treatment appear as straight lines between recorded points. However, in the natural substrate treatment, in contrast to the uniform swim paths in the other two treatments, we observed fish swimming throughout the flume near the substrate with no clear preference for flume walls. There appeared to be no directional pattern to swim paths in the natural substrate treatment other than upstream, and fish made lateral movements across the flume, reversals in direction (including downstream), and entered and exited the test section in variable locations across the width of the flume (Figure 2).

bare flume

Z $=$ longnose dace
= southern leatherside chub

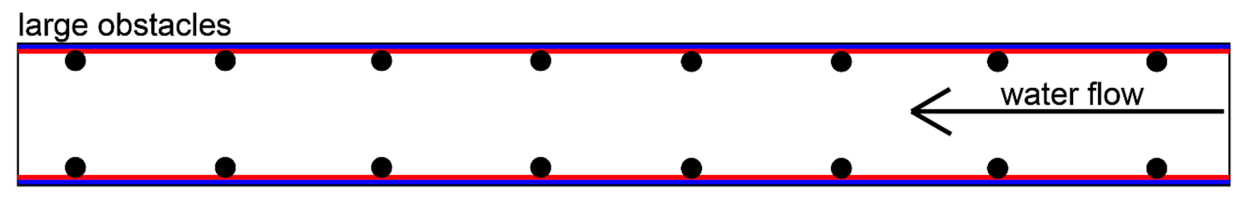

natural substrate

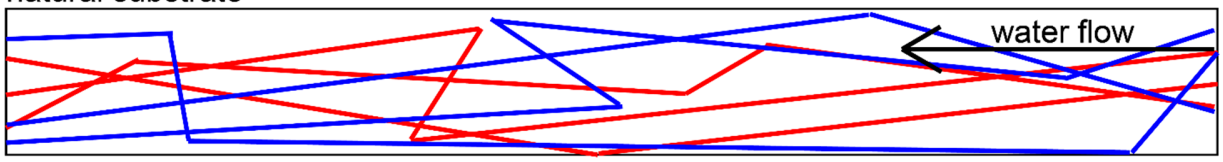

Figure 2. Plan view of sample swim paths of southern leatherside chub and longnose dace in bare flume (top), large flow obstacles (middle), and natural substrate (bottom) treatments in the $10 \mathrm{~m}$ test section of the flume. The flume test section is $10 \mathrm{~m}$ in length and $1.2 \mathrm{~m}$ in width, and the position and relative size of the large obstacles are indicated by the black circles. In these two treatments, the red line indicating longnose dace and the blue line indicating southern leatherside chub are slightly offset to show color differences, but do not represent differences in swim path. 


\subsection{Passage Success and Time}

At least $70 \%$ of individuals in both species among all three treatments successfully passed through the test flume (Figure 3a). There was no relationship between passage success of fish and substrate type, fish species, or their interaction (Table 1). In contrast, substrate type, fish species, and their interaction were significant predictors of passage time (Table 2). Southern leatherside chub passed through the flume about two to four times faster than longnose dace. Both species took longer to pass through the large flow obstacles treatment compared to the bare flume or natural substrate. This effect was more pronounced in southern leatherside chub (Figure 3b).

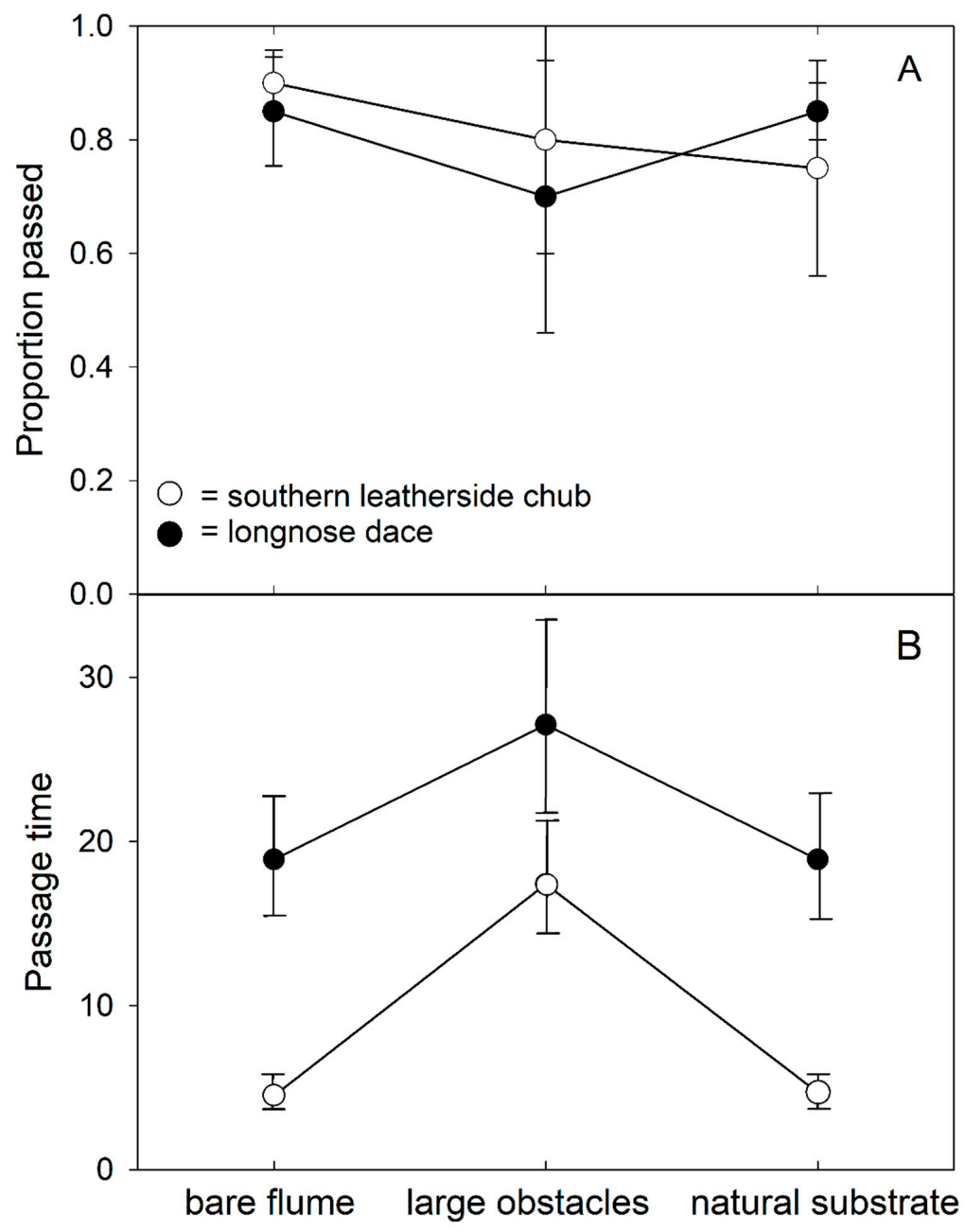

\section{Substrate treatment}

Figure 3. Mean ( $\pm 1 \mathrm{SE}$ ) of (A) passage rate, and (B) passage time (in min) through the flume based on substrate type and fish species.

Table 1. Logistic regression analysis for fish passage success through the flume comparing the three substrate treatments (bare flume, large obstacles, and natural substrate) and two fish species (southern leatherside chub and longnose dace), and their interaction.

\begin{tabular}{cccc}
\hline Source of Variation & df & Chi-Square & P-Value \\
\hline species & 1 & 0.09 & 0.76 \\
substrate & 2 & 2.09 & 0.35 \\
species $\times$ substrate & 2 & 1.43 & 0.49 \\
\hline
\end{tabular}


Table 2. Analysis of variance for time of fish passage through the flume comparing the three substrate treatments (bare flume, large obstacles, and natural substrate) and two fish species (southern leatherside chub and longnose dace), and their interaction.

\begin{tabular}{cccc}
\hline Source of Variation & df & F Value & P-Value \\
\hline species & $1 / 89$ & 46.31 & $<0.0001$ \\
substrate & $2 / 89$ & 11.94 & $<0.0001$ \\
species $\times$ substrate & $2 / 89$ & 3.96 & 0.0224 \\
\hline
\end{tabular}

\subsection{Velocity Profiles and Swim Paths}

The three substrate treatments created dramatically different velocity patterns in the test field. The lowest velocities in the bare flume were near the flume walls. Velocity increased uniformly from the walls to the center of the flume, where velocity was highest (Figure 4). In the large flow obstacle treatment, the areas of lowest velocity were located downstream from the obstacles and between the obstacles and the wall of the flume. Like the bare flume, the highest velocity in the large flow obstacles treatment was located in the center of the flume. (Figure 4). In contrast to both of these treatments, the natural cobble substrate produced a complex, nonuniform velocity pattern with low and high velocities distributed throughout the entire flume area (Figure 4).
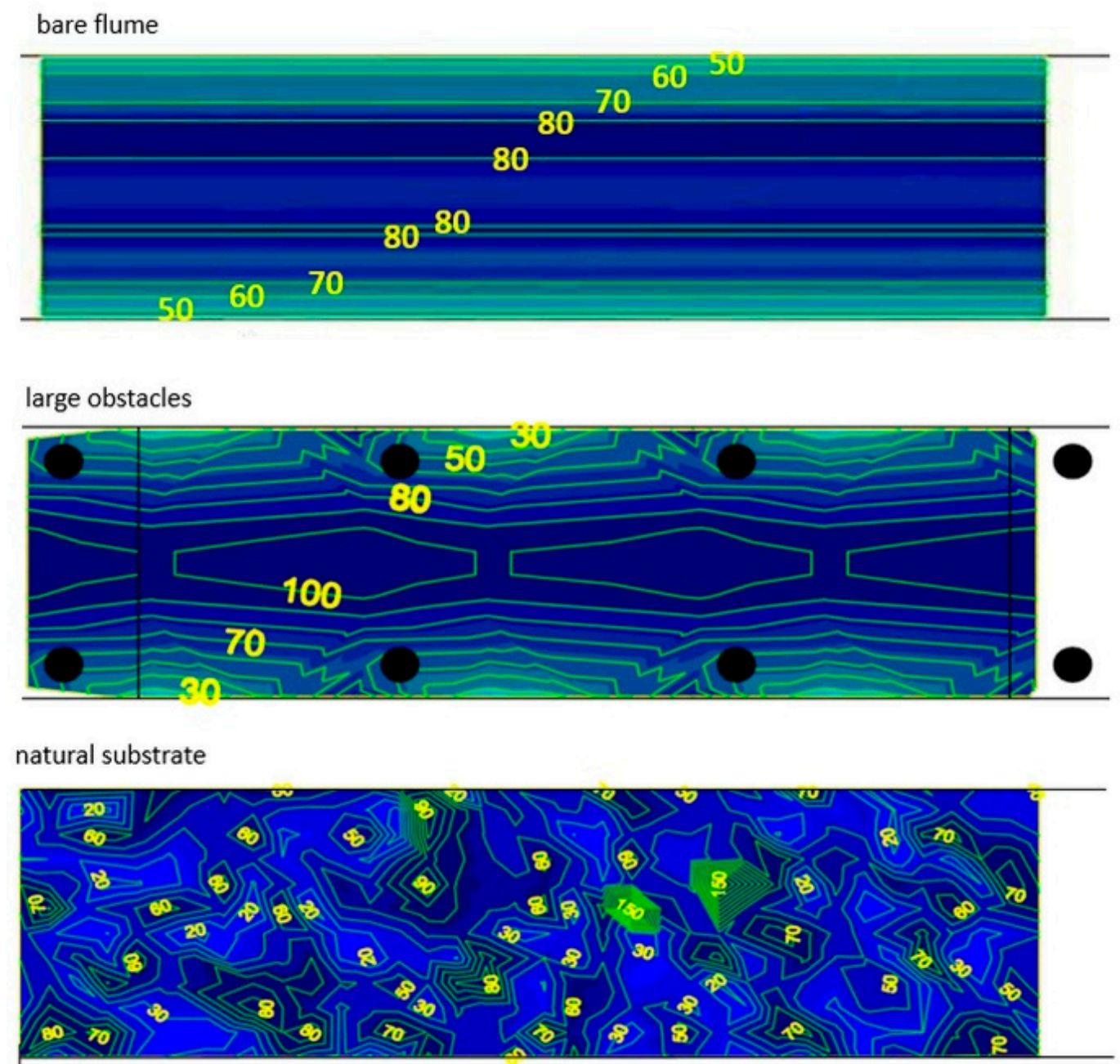

Figure 4. Plan view of velocity field in experimental flume for substrate treatments of bare flume (top), large flow obstacles (middle), and natural substrate (bottom). Length of the section shown above was $3.5 \mathrm{~m}$. Water flow is from right to left. Velocity contours are in units of $\mathrm{cm} / \mathrm{s}$, and are shown at a flow rate of $0.91 \mathrm{~m} / \mathrm{s}$. 
The velocity experienced by fish for simulated swim paths in the bare flume was constant at about $47 \mathrm{~cm} / \mathrm{s}$ throughout the length of the flume near the flume walls (Figure 5a). In the large obstacle treatment, the velocity profile of simulated swim paths fluctuated regularly between velocities of $28 \mathrm{~cm} / \mathrm{s}$ and $80 \mathrm{~cm} / \mathrm{s}$ as the fish moved along the flume wall past the obstacles (Figure $5 \mathrm{a}$ ). In the natural substrate treatment, the velocity profile of the simulated swim path fluctuated irregularly between about $15 \mathrm{~cm} / \mathrm{s}$ and $49 \mathrm{~cm} / \mathrm{s}$ as the fish moved in irregular paths across the flume following a low-velocity path (Figure $5 b$ ).

a)

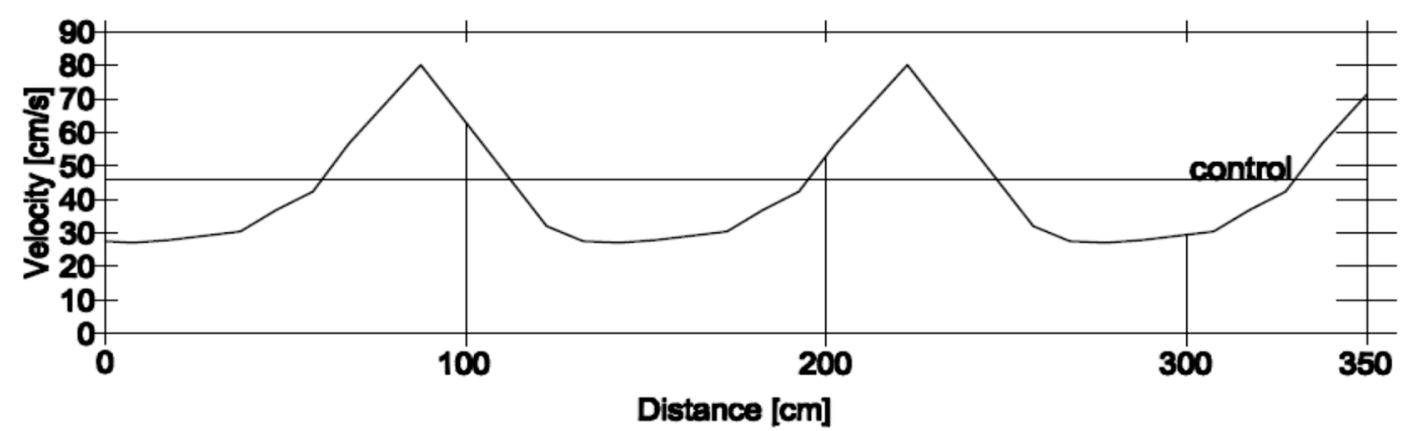

b)

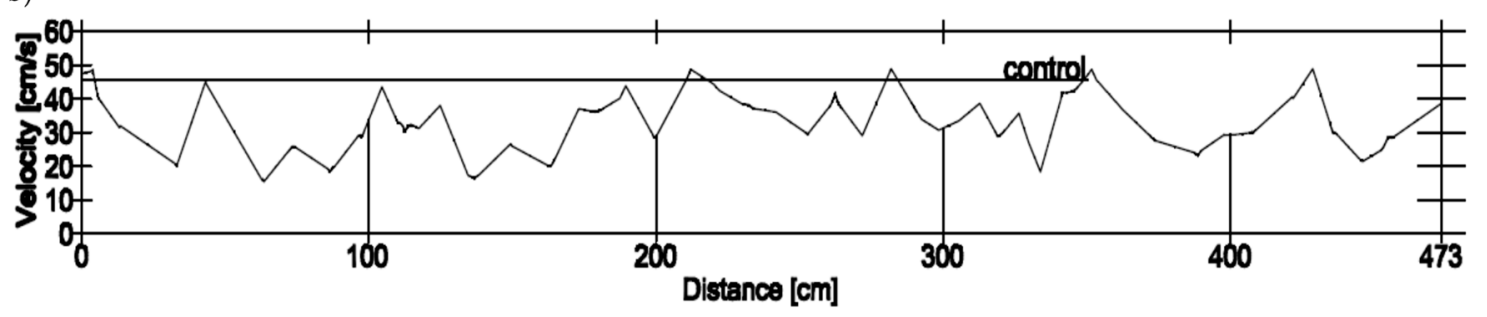

Figure 5. Velocity profiles for longnose dace flow conditions with velocity measurements taken $1 \mathrm{~cm}$ above the substrate along simulated typical swim paths; (a) bare flume (designated as control) and large flow obstacles treatment, and (b) bare flume (designated as control) and natural substrate treatment. The distance is longer in the natural substrate treatment because the swim path was not straight.

\section{Discussion}

Successful restoration of stream habitats depends on connectivity of fish assemblages within the stream system. Culverts can become barriers to fish movement and lead to fragmentation of otherwise suitable habitat [63]. The results of this study indicate that small-bodied stream fish, such as longnose dace and southern leatherside chub, select swim paths of low velocity to pass through culverts. It also suggests that natural substrate positively affects the ability of small fish to swim upstream by providing areas of reduced velocity. Fish consistently utilized paths of low velocity when navigating upstream through the experimental flume. In all treatments, fish swam close to the substrate, where velocity is lowest. Neither species used the midwater area, even though southern leatherside chub typically frequent midwater habitats [64]. The swim paths of fish also mirrored the path of lowest velocity. In the bare flume trial, fish swam up the side of the flume, where velocity was lowest [65]. Conversely, the natural substrate treatment produced a highly variable velocity profile [66]. The swim paths of fish in the natural substrate treatment reflected this variability. Swim paths lacked a clear pattern and covered the entirety of the flume bed, mirroring the non-uniformity of the velocity profile.

The difference in passage time between the two species is likely due to differences in swimming behavior, which is influenced by morphological features, such as rostrum shape, size of pectoral fins, and body shape [28]. Behavioral and morphological responses to high velocities differ between functional groups [23,25]. In high velocities, longnose dace exhibit a bracing behavior that allows them to maintain position without expending much energy $[45,49,67]$. Southern leatherside chub, 
on the other hand, must swim continuously to maintain position, even in lower velocity zones [49]. These behavioral adaptations minimize energy expenditure [25,40,45]; for southern leatherside chub, rapid passage through high velocity areas conserves energy, whereas longnose dace are able to brace without increasing energy expenditure $[25,46]$. Rough bottom substrates may provide an energetic advantage to both species if substratum dimensions are similar to the body size of the fish $[27,46]$. Fish seek refuge from the main current by "flow refuging" in areas of reduced flow velocity [44]. As the water velocity increases, the maximum distance that fish can travel without resting decreases $[68,69]$.

The availability of low-velocity zones is an important factor to consider in high velocity flow fields [70]. Our observations support the hypothesis that small, weak-swimming fish navigate upstream by using paths of low velocity $[15,33]$. Our findings are also consistent with reports of small-bodied fish moving upstream along the side of the flume in the reduced velocity zone or skimming the substrate $[15,28,33,34,71]$. This study suggests that average cross-sectional velocities may not provide a good metric for predicting passage of small-bodied stream fish, because both midwater and benthic swimmers use the low-velocity area directly above the substrate for passage. This study also indicates that constricted structures that create high velocities are more likely to be a barrier to midwater swimmers, which don't have energy-saving bracing behaviors like benthic species [49].

The use of natural substrate and artificial or natural rugosities to create low velocity zones gives greater flexibility to culvert design in stream restoration plans. The average cross-sectional velocity in a culvert is used to accommodate the prolonged swimming speed of the weakest swimmer [72], which results in dramatically increased culvert sizes [15]. The size of the smallest fish that must transverse the culvert influences its design and cost [12]. These results demonstrate that for multiple species of small-bodied fish, upstream passage is greatly facilitated by lining the culvert bottom with the substrate found in the fish species' native environment. This is a simple and economical mitigation compared to the expense of replacing or otherwise modifying the culvert barrel.

Other studies on fish passage have shown that in addition to velocity, turbulence can have strong effects on swimming behavior and movement $[9,12,73]$. We did not measure turbulence in the bare flume or large obstacles treatments; however, we did observe that fish in the large obstacle treatment did not use the turbulent wake region downstream of the obstacles, suggesting that perhaps turbulence influenced swim path behavior in this treatment. In the natural substrate treatment, we did not observe any noticeable effects of turbulence. Turbulence was likely lower in the natural substrate treatment because the size of the substrate particles were smaller than in the large obstacle treatment. Effects of combined velocity and turbulence measurements would be an interesting area for future experimental research.

In summary, our data suggest that the type of substrate in a culvert can have a strong influence on movement and swimming behavior of both mid-water and benthic-oriented fish. Natural cobble substrate provides a much less restrictive environment for passage with multiple low velocity paths, compared to large obstacles or a bare culvert. These results add to our understanding of how small stream fish move through high flow environments created by culverts and other flow restrictions.

Author Contributions: M.C.B. and R.H.H. conceived and designed the experiments. L.E.W. and S.K.M. performed the experiments. M.C.B., L.E.W., R.R., and S.K.M. analyzed the data; R.R. and R.H.H. contributed reagents, materials, and analysis tools. K.J., M.C.B., R.R., and L.E.W. wrote the paper.

Acknowledgments: This work has been carried out with funding from the Utah Department of Transportation (UDOT). Thanks for knowledge and assistance in fish capture and care from Eric Billman and undergraduates in the Brigham Young University Department of Biology. Additional thanks to Karsten Busby, David Anderson, and Rodney Mayo for technical and logistical assistance in lab experiments. All fish capture, care, and testing was in accordance with the Institutional Animal Care and Use Committee (IACUC) protocol \#10-0401.

Conflicts of Interest: The authors declare no conflict of interest. The funding sponsors had no role in the design of the study; in the collection, analyses, or interpretation of data; in the writing of the manuscript, and in the decision to publish the results. 


\section{References}

1. Starrs, D.; Ebner, B.; Lintermans, M.; Fulton, C. Using sprint swimming performance to predict upstream passage of the endangered Macquarie perch in a highly regulated river. Fish. Manag. Ecol. 2011, 18, 360-374. [CrossRef]

2. Price, D.M.; Quinn, T.; Barnard, R.J. Fish passage effectiveness of recently constructed road crossing culverts in the Puget Sound region of Washington State. N. Am. J. Fish. Manag. 2010, 30, 1110-1125. [CrossRef]

3. Warren Jr, M.L.; Pardew, M.G. Road crossings as barriers to small-stream fish movement. Trans. Am. Fish. Soc. 1998, 127, 637-644. [CrossRef]

4. Blank, M.; Cahoon, J.; Burford, D.; McMahon, T.; Stein, O. Studies of Fish Passage through Culverts in Montana; Road Ecology Center: Berkeley, CA, USA, 2005.

5. Clark, S.P.; Toews, J.S.; Tkach, R. Beyond average velocity: Modelling velocity distributions in partially filled culverts to support fish passage guidelines. Int. J. River Basin Manag. 2014, 12, 101-110. [CrossRef]

6. MacPherson, L.M.; Sullivan, M.G.; Foote, A.L.; Stevens, C.E. Effects of culverts on stream fish assemblages in the Alberta foothills. N. Am. J. Fish. Manag. 2012, 32, 480-490. [CrossRef]

7. Park, D.; Sullivan, M.; Bayne, E.; Scrimgeour, G. Landscape-level stream fragmentation caused by hanging culverts along roads in Alberta's boreal forest. Can. J. For. Res. 2008, 38, 566-575. [CrossRef]

8. Gibson, R.J.; Haedrich, R.L.; Wernerheim, C.M. Loss of fish habitat as a consequence of inappropriately constructed stream crossings. Fisheries 2005, 30, 10-17. [CrossRef]

9. Rodríguez, T.T.; Agudo, J.P.; Mosquera, L.P.; González, E.P. Evaluating vertical-slot fishway designs in terms of fish swimming capabilities. Ecol. Eng. 2006, 27, 37-48. [CrossRef]

10. Winston, M.R.; Taylor, C.M.; Pigg, J. Upstream extirpation of four minnow species due to damming of a prairie stream. Trans. Am. Fish. Soc. 1991, 120, 98-105. [CrossRef]

11. Roscoe, D.W.; Hinch, S.G. Effectiveness monitoring of fish passage facilities: Historical trends, geographic patterns and future directions. Fish Fish. 2010, 11, 12-33. [CrossRef]

12. Mallen-Cooper, M.; Brand, D. Non-salmonids in a salmonid fishway: What do 50 years of data tell us about past and future fish passage? Fish. Manag. Ecol. 2007, 14, 319-332. [CrossRef]

13. Franklin, P.A.; Bartels, B.; Ecosystems, F. Restoring connectivity for migratory native fish in a New Zealand stream: Effectiveness of retrofitting a pipe culvert. Aquat. Conserv. Mar. 2012, 22, 489-497. [CrossRef]

14. House, M.R.; Pyles, M.R.; White, D. Velocity distributions in streambed simulation culverts used for fish passage. J. Am. Water Resour. Assoc. 2005, 41, 209-217. [CrossRef]

15. Richmond, M.C.; Deng, Z.; Guensch, G.R.; Tritico, H.; Pearson, W.H. Mean flow and turbulence characteristics of a full-scale spiral corrugated culvert with implications for fish passage. Ecol. Eng. 2007, 30, 333-340. [CrossRef]

16. Belford, D.A.; Gould, W.R. An evaluation of trout passage through six highway culverts in Montana. N. Am. J. Fish. Manag. 1989, 9, 437-445. [CrossRef]

17. Fitch, G.M. Nonanadromous Fish Passage in Highway Culverts. Final Report; The National Academies of Sciences, Engineering, and Medicine: Washington, DC, USA, 1995.

18. Mallen-Cooper, M.; Stuart, I. Optimising Denil fishways for passage of small and large fishes. Fish. Manag. Ecol. 2007, 14, 61-71. [CrossRef]

19. Cooke, S.J.; Bunt, C.M.; Hamilton, S.J.; Jennings, C.A.; Pearson, M.P.; Cooperman, M.S.; Markle, D.F. Threats, conservation strategies, and prognosis for suckers (Catostomidae) in North America: Insights from regional case studies of a diverse family of non-game fishes. Biol. Conserv. 2005, 121, 317-331. [CrossRef]

20. Hard, A.; Kynard, B. Video evaluation of passage efficiency of American shad and sea lamprey in a modified Ice Harbor fishway. N. Am. J. Fish. Manag. 1997, 17, 981-987. [CrossRef]

21. Laine, A.; Kamula, R.; Hooli, J. Fish and lamprey passage in a combined Denil and vertical slot fishway. Fish. Manag. Ecol. 1998, 5, 31-44. [CrossRef]

22. Moser, M.L.; Matter, A.L.; Stuehrenberg, L.C.; Bjornn, T.C. Use of an extensive radio receiver network to document Pacific lamprey (Lampetra tridentata) entrance efficiency at fishways in the Lower Columbia River, USA. In Aquatic Telemetry; Springer: New York, NY, USA, 2002; pp. 45-53.

23. Tudorache, C.; Viaene, P.; Blust, R.; Vereecken, H.; De Boeck, G. A comparison of swimming capacity and energy use in seven European freshwater fish species. Ecol. Freshw. Fish 2008, 17, 284-291. [CrossRef] 
24. Knaepkens, G.; Baekelandt, K.; Eens, M. Fish pass effectiveness for bullhead (Cottus gobio), perch (Perca fluviatilis) and roach (Rutilus rutilus) in a regulated lowland river. Ecol. Freshw. Fish 2006, 15, 20-29. [CrossRef]

25. Facey, D.; Grossman, G. The relationship between water velocity, energetic costs, and microhabitat use in four North American stream fishes. Hydrobiologia 1992, 239, 1-6. [CrossRef]

26. Peake, S.; Beamish, F.W.; McKinley, R.; Scruton, D.; Katopodis, C. Relating swimming performance of lake sturgeon, Acipenser fulvescens, to fishway design. Can. J. Fish. Aquat. Sci. 1997, 54, 1361-1366. [CrossRef]

27. Downie, A.T.; Kieffer, J.D. A split decision: The impact of substrate type on the swimming behaviour, substrate preference and UCrit of juvenile shortnose sturgeon (Acipenser brevirostrum). Environ. Biol. Fishes 2017, 100, 17-25. [CrossRef]

28. Kieffer, J.; Arsenault, L.; Litvak, M. Behaviour and performance of juvenile shortnose sturgeon Acipenser brevirostrum at different water velocities. J. Fish Biol. 2009, 74, 674-682. [CrossRef] [PubMed]

29. May, L.; Kieffer, J. The effect of substratum type on aspects of swimming performance and behaviour in shortnose sturgeon Acipenser brevirostrum. J. Fish Biol. 2017, 90, 185-200. [CrossRef] [PubMed]

30. Branco, P.; Santos, J.M.; Katopodis, C.; Pinheiro, A.; Ferreira, M.T. Pool-type fishways: Two different morpho-ecological cyprinid species facing plunging and streaming flows. PLoS ONE 2013, 8, e65089. [CrossRef]

31. Romão, F.; Quaresma, A.L.; Branco, P.; Santos, J.M.; Amaral, S.; Ferreira, M.T.; Katopodis, C.; Pinheiro, A.N. Passage performance of two cyprinids with different ecological traits in a fishway with distinct vertical slot configurations. Ecol. Eng. 2017, 105, 180-188. [CrossRef]

32. Doehring, K.; Young, R.G.; McIntosh, A.R. Factors affecting juvenile galaxiid fish passage at culverts. Mar. Freshw. Res. 2011, 62, 38-45. [CrossRef]

33. Johnson, G.E.; Pearson, W.H.; Southard, S.L.; Mueller, R.P. Upstream movement of juvenile coho salmon in relation to environmental conditions in a culvert test bed. Trans. Am. Fish. Soc. 2012, 141, 1520-1531. [CrossRef]

34. Pearson, W.; Richmond, M.; Johnson, G.; Sargeant, S.; Mueller, R.; Cullinan, V.; Deng, Z.; Dibrani, B.; Guensch, G.; May, C. Protocols for Evaluation of Upstream Passage of Juvenile Salmonids in an Experimental Culvert Test Bed; Report No. PNWD-3525; Battelle Memorial Institute: Richland, WA, USA, 2005.

35. Kristensen, E.A.; Baattrup-Pedersen, A.; Thodsen, H. An evaluation of restoration practises in lowland streams: Has the physical integrity been re-created? Ecol. Eng. 2011, 37, 1654-1660. [CrossRef]

36. Rodgers, E.M.; Heaslip, B.M.; Cramp, R.L.; Riches, M.; Gordos, M.A.; Franklin, C.E. Substrate roughening improves swimming performance in two small-bodied riverine fishes: Implications for culvert remediation and design. Conserv. Physiol. 2017, 5, cox034. [CrossRef] [PubMed]

37. Pedersen, M.L.; Kristensen, E.A.; Kronvang, B.; Thodsen, H. Ecological effects of re-introduction of salmonid spawning gravel in lowland Danish streams. River Res. Appl. 2009, 25, 626-638. [CrossRef]

38. Santos, J.M.; Branco, P.; Katopodis, C.; Ferreira, T.; Pinheiro, A. Retrofitting pool-and-weir fishways to improve passage performance of benthic fishes: Effect of boulder density and fishway discharge. Ecol. Eng. 2014, 73, 335-344. [CrossRef]

39. Heimerl, S.; Hagmeyer, M.; Echteler, C. Numerical flow simulation of pool-type fishways: New ways with well-known tools. Hydrobiologia 2008, 609, 189. [CrossRef]

40. Liao, J.C. A review of fish swimming mechanics and behaviour in altered flows. Philos. Trans. R. Soc. Lond. $B$ Biol. Sci. 2007, 362, 1973-1993. [CrossRef] [PubMed]

41. Blake, R. The biomechanics of intermittent swimming behaviours in aquatic vertebrates. In Biomechanics in Animal Behaviour; CRC Press: Boca Raton, FL, USA, 2000; pp. 79-103.

42. Nursall, J. Some behavioral interactions of spottail shiners (Notropis hudsonius), yellow perch (Perca flavescens), and northern pike (Esox lucius). J. Fish. Board Can. 1973, 30, 1161-1178. [CrossRef]

43. Webb, P.W. Control of posture, depth, and swimming trajectories of fishes. Integr. Comp. Biol. 2002, 42, 94-101. [CrossRef]

44. Webb, P.W. Entrainment by river chub Nocomis micropogon and smallmouth bass Micropterus dolomieu on cylinders. J. Exp. Biol. 1998, 201, 2403-2412.

45. Ward, D.L.; Schultz, A.A.; Matson, P.G. Differences in swimming ability and behavior in response to high water velocities among native and nonnative fishes. Environ. Biol. Fishes 2003, 68, 87-92. [CrossRef]

46. Mullen, D.M.; Burton, T.M. Size-related habitat use by longnose dace (Rhinichthys cataractae). Am. Midl. Nat. 1995, 133, 177-183. [CrossRef] 
47. Webb, P.W.; Gerstner, C.L.; Minton, S.T. Station-holding by the mottled sculpin, Cottus bairdi (Teleostei: Cottidae), and other fishes. Copeia 1996, 488-493. [CrossRef]

48. Edwards, E.A.; Li, H.; Schreck, C.B. Habitat Suitability Index Models: Longnose Dace; Western Energy and Land Use Team: Fort Collins, CO, USA, 1983.

49. Aedo, J.; Belk, M.C.; Hotchkiss, R.H. Swimming Performance and Morphology of Utah Fishes: Critical Information for Culvert Design in Utah Streams; The National Academies of Sciences, Engineering, and Medicine: Washington, DC, USA, 2009.

50. Wilson, K.W.; Belk, M.C. Habitat characteristics of leatherside chub (Gila copei) at two spatial scales. West. N. Am. Nat. 2001, 61, 36-42.

51. Belk, M.; Johnson, J.; Wilson, K.; Smith, M.; Houston, D. Variation in intrinsic individual growth rate among populations of leatherside chub (Snyderichthys copei Jordan \& Gilbert): Adaptation to temperature or length of growing season? Ecol. Freshw. Fish 2005, 14, 177-184.

52. Ward, D.; Maughan, O.; Bonar, S. A Variable-Speed Swim Tunnel for Testing the Swimming Ability of Age-0 Fish. N. Am. J. Aquac. 2002, 64, 228-231. [CrossRef]

53. Peake, S. An evaluation of the use of critical swimming speed for determination of culvert water velocity criteria for smallmouth bass. Trans. Am. Fish. Soc. 2004, 133, 1472-1479. [CrossRef]

54. Peake, S.J.; Farrell, A.P. Postexercise physiology and repeat performance behaviour of free-swimming smallmouth bass in an experimental raceway. Physiol. Biochem. Zool. 2005, 78, 801-807. [CrossRef]

55. Castro-Santos, T. Optimal swim speeds for traversing velocity barriers: An analysis of volitional high-speed swimming behavior of migratory fishes. J. Exp. Biol. 2005, 208, 421-432. [CrossRef]

56. Schlichting, H. Boundary-Layer Theory, 7th ed.; McGraw-Hill Book Co.: New York, NY, USA, 1979.

57. Belk, M.C.; Benson, L.J.; Rasmussen, J.; Peck, S.L. Hatchery-induced morphological variation in an endangered fish: A challenge for hatchery-based recovery efforts. Can. J. Fish. Aquat. Sci. 2008, 65, 401-408. [CrossRef]

58. Song, T.; Chiew, Y. Turbulence measurement in nonuniform open-channel flow using acoustic Doppler velocimeter (ADV). J. Eng. Mech. 2001, 127, 219-232. [CrossRef]

59. SonTek. ADV Principles of Operation; Sontek Inc.: San Diego, CA, USA, 2001.

60. Lockhart, S. Tutorial Guide to AutoCad; Schroff Development Corporation: Mission, KS, USA, 2012.

61. SAS Institute. SAS-STAT Software: Changes and Enhancements through Release 6.12; SAS Institute: Cary, NC, USA, 1997.

62. Littell, R.C.; Milliken, G.A.; Stroup, W.W.; Wolfinger, R.D.; Schabenberger, O. SAS for Mixed Models; SAS Institute: Cary, NC, USA, 2007.

63. Stoll, S.; Kail, J.; Lorenz, A.W.; Sundermann, A.; Haase, P. The importance of the regional species pool, ecological species traits and local habitat conditions for the colonization of restored river reaches by fish. PLoS ONE 2014, 9, e84741. [CrossRef] [PubMed]

64. Sigler, W.F.; Sigler, J.W. Fishes of Utah: A Natural History; University of Utah Press Salt: Lake City, UT, USA, 1996.

65. Ead, S.; Rajaratnam, N.; Katopodis, C.; Ade, F. Turbulent open-channel flow in circular corrugated culverts. J. Hydraul. Eng. 2000, 126, 750-757. [CrossRef]

66. Chin, C.-L.; Murray, D.W. Variation of velocity distribution along nonuniform open-channel flow. J. Hydraul. Eng. 1992, 118, 989-1001. [CrossRef]

67. Billman, E.J.; Pyron, M. Evolution of form and function: Morphology and swimming performance in North American minnows. J. Freshw. Ecol. 2005, 20, 221-232. [CrossRef]

68. Boubée, J.; Jowett, I.; Nichols, S.; Williams, E. Fish Passage at Culverts: A Review, with Possible Solutions for New Zealand Indigenous Species; Department of Conservation: Wellington, New Zealand, 1999.

69. Mitchell, C. Swimming performances of some native freshwater fishes. N. Z. J. Mar. Freshw. Res. 1989, 23, 181-187. [CrossRef]

70. MacDonald, J.; Davies, P. Improving the upstream passage of two galaxiid fish species through a pipe culvert. Fish. Manag. Ecol. 2007, 14, 221-230. [CrossRef]

71. Powers, P.; Bates, K. Culvert Hydraulics Related to Upstream Juvenile Salmon Passage; Washington Department of Fish and Wildlife, Land and Restoration Services Program, Environmental Engineering Services: Washington, DC, USA, 1997. 
72. Hotchkiss, R.H.; Frei, C.M. Design for Fish Passage at Roadway-Stream Crossings: Synthesis Report; Federal Highway Administration: Washington, DC, USA, 2007.

73. Lacey, R.J.; Neary, V.S.; Liao, J.C.; Enders, E.C.; Tritico, H.M. The IPOS framework: Linking fish swimming performance in altered flows from laboratory experiments to rivers. River Res. Appl. 2012, 28, 429-443. [CrossRef] 